\title{
Z PROBLEMATYKI ODPOWIEDZIALNOŚCI KARNEJ INTRANEUSA ZA NIEWYKONAWCZE FORMY WSPÓŁDZIAŁANIA PRZESTECPNEGO (UWAGI NA TLE PRZESTĘPSTWA DZIECIOBÓJSTWA) ${ }^{1}$
}

I. Jak kształtuje się karnoprawna ocena czynu matki, polegającego na niewykonawczym współdziałaniu w zabójstwie jej dziecka w okresie porodu pod wpływem jego przebiegu? Na to pytanie w literaturze z zakresu prawa karnego znajdujemy dwie różne odpowiedzi. W świetle pierwszej z nich przeważającej, czyn taki należy kwalifikować na podstawie art. 149 k.k. jako uprzywilejowany typ zabójstwa ${ }^{2}$. Natomiast w świetle drugiej z nich czyn ten stanowi zwykłe zabójstwo, zależnie od okoliczności in concreto - typu zasadniczego albo kwalifikowanego. W konsekwencji także podstawą wymiaru kary nie będzie art. 149 k.k., lecz art. $148 \S 1,2$ albo 3 k.k. Za takim rozwiązaniem opowiada się Łukasz Pohl ${ }^{3}$. Tenże autor wychodzi z założenia, że wszystkie cztery niewykonawcze formy współdziałania przestępnego to nie formy zjawiskowe typu czynu zabronionego pod groźbą kary, ale odrębne typy czynów zabronionych, mające własne zestawy znamion. Następnie autor wskazuje, że w świetle priorytetowej kodeksowej zasady subiektywizmu, niezbędne - dla przeprowadzenia poprawnej kwalifikacji czynu matki popełnionego w ramach niewykonawczych form współdziałania przestępnego - jest wizualizowane przez matkę, nie zaś „faktycznie zrealizowane zachowanie się innej osoby będące czynem zabronionym" . Z tego punktu widzenia wizualizowane przez matkę nie jest dzieciobójstwo, lecz zabójstwo albo typu zasadniczego (art. 148 § 1 k.k.), albo typu kwalifikowanego (art. $148 \S 2$ pkt 1 k.k.). Jest tak dlatego - pisze Pohl że matka wcale nie wizualizuje dzieciobójstwa, ponieważ zdaje sobie w pełni sprawę z faktu, iż bezpośredni wykonawca nie jest matką dziecka, w związku z czym nie może być on sprawcą dzieciobójstwa. Ustalenia te niezawodnie pro-

${ }^{1}$ Uwidocznione $\mathrm{w}$ tytule niewykonawcze formy współdziałania przestępnego to: sprawstwo kierownicze, sprawstwo polecające, jak również podżeganie i pomocnictwo. Należy dodać, że zawarte w opracowaniu rozważania mają charakter ogólniejszy i wybiegają poza problematykę związaną z przestępstwem dzieciobójstwa. Dotyczą więc wszystkich przestępstw indywidualnych niewłaściwych typu uprzywilejowanego, na tle których nurtować może kwestia karnoprawnej oceny czynu intraneusa za niewykonawcze współdziałanie.

2 Pilarczyk (2014): 89-90, przyp. 48 oraz podane tam prace.

${ }^{3}$ Pohl (2013): 291-303. Z przykrością należy odnotować fakt, że powyższe, jakże doniosłe w nauce prawa karnego, opracowanie Pohla całkowitym milczeniem pominął ostatnio Kluza (2018): 15-24.

${ }^{4}$ Pohl (2013): 299. 
wadzą Pohla do twierdzenia, że właściwa kwalifikacja prawna czynu matki polegającego na niewykonawczej formie współdziałania przestępnego w zabójstwie jej dziecka będzie przepis statuujący zabójstwo typu zasadniczego w połączeniu z odpowiednią formą współdziałania przestępnego matki ${ }^{5}$. W takim przypadku podstawę wymiaru kary kształtować będzie art. $148 \S 1$ k.k., a nie art. 149 k.k. ${ }^{6}$

Powyższe stanowisko ma swe bezpośrednie źródło w pojmowaniu kodeksowego określenia „formy popełnienia przestępstwa”. Mianowicie Pohl, bazując na ustaleniach stricte teoretycznoprawych, stoi na stanowisku, że określenie to - na normatywnym poziomie odczytania tekstu prawnego - dowodzi istnienia odrębnej normy sankcjonowanej dla każdej z wyodrębnionych form popełnienia czynu zabronionego pod groźbą kary, „której przekroczenie jest możliwe jedynie zachowaniem ściśle określonego rodzaju - rodzaju determinującego wyodrębnienie $\mathrm{w}$ prawie karnym różnych form popełnienia czynu zabronionego pod groźbą kary"'. Z tego powodu nie ma podstaw do wyodrębniania głównego (rodzajowego) typu czynu zabronionego pod groźbą kary8. Dodatkowo podkreśla się, że przepisy typizujące części szczególnej Kodeksu karnego zakazują jedynie określonych czynów kwalifikowanych jako wykonawcze (zorientowane są więc wyłącznie na jednosprawstwo i współsprawstwo) ${ }^{9}$. Wedle tego ujęcia to przepisy art. $18 \S 1,2$ i 3 k.k., a nie przepisy części szczególnej k.k. są tymi, które zrębowo wysłowiają normę sankcjonowaną zakazującej odpowiednio: sprawstwa kierowniczego, sprawstwa polecającego, podżegania i pomocnictwa. Dla tych form popełnienia przestępstwa funkcję typizująca pełnią przepisy art. 18 § 1 , 2 i 3 k.k., nie zaś przepisy części szczególnej Kodeksu karnego. Krótko mówiąc, w warstwie deskryptywnej i normatywnej, przekonuje Pohl, przepisy części szczególnej k.k. nie odsyłają do niewykonawczych form współdziałania przestępnego ${ }^{10}$. Jest to kluczowe ustalenia w perspektywie dalszych uwag.

II. Ponieważ na mocy tzw. praw rzeczywistości w formie niewykonawczej nie można dokonać czynu zabronionego określonego w części szczególnej k.k., a więc np. nie można zabić człowieka wyłącznie przez nakłanianie innej osoby do dokonania zabójstwa, to tym samym podżegacz do zabójstwa nie przekracza normy sankcjonowanej zakazującej zabójstwa człowieka. Podżegacz przekracza inną normę sankcjonowana, mianowicie normę zakazująca nakłaniania innej osoby do dokonania zabójstwa. Zarazem czyn nakłaniania do zabójstwa

${ }^{5}$ Pohl (2013): 300-301.

${ }^{6}$ Dalej Pohl podnosi, że taki wynik wykładniczy prowadzi do nieuzasadnionego zróżnicowania odpowiedzialności matki, która zabiła swoje dziecka, i matki, która swojego dziecka nie zabiła. Popada więc w konflikt z wartościami przypisywanymi racjonalnemu prawodawcy. Konflikt ten może zostać zażegnany dwojako: albo w drodze przełamania jednoznacznego wyniku wykładni językowej, albo przez zmianę ustawy. Pohl zgłasza odpowiedni postulat de lege ferenda. Bliżej zob. Pohl (2013): 302-303.

7 Pohl (2019): 185.

8 Pohl (2019): 151-152.

9 Pohl (2018a): 15.

10 Pohl (2010): 174. 
jest czynem różnym od czynu zabicia człowieka. Samym bowiem nakłanianiem innej osoby do zabicia człowieka nie można wytworzyć stanu (skutku) polegającego na śmierci człowieka, podobnie jak poleceniem zabicia człowieka tudzież kierując tylko postępowaniem innej osoby wytwarzającej stan rzeczy polegający na zabiciu człowieka ${ }^{11}$. Jest tak dlatego, że podżegacz nie może „zabić” człowieka, ale co najwyżej „nakłonić do zabicia”. „Zabić człowieka można tylko wykonaniem takiego czynu"12. Twierdzenie to znajduje swoje mocne uzasadnienie w pochodzacej od Georga H. von Wrighta skutkowej koncepcji czynu. W ogromnym uproszczeniu koncepcja ta zakłada, że czyn jest definiowany przez zmianę, którą powoduje. Biorąc przykładowo: czynem otwarcia okna jest czyn przekształcający świat, w którym okno jest zamknięte, w świat, w którym następuje zmiana - okno jest otwarte ${ }^{13}$. Jeżeli zatem w ramach czynu podżegania matka rodzącego się dziecka nie może wytworzyć stanu rzeczy polegającego na „zabiciu” ('śmierci) tego dziecka, to nie może być sprawcą dzieciobójstwa określonego w art. 149 k.k.

III. Sprawa nie jest prosta. Wydaje się jednak, że do tego - siłą rzeczy wybitnie hasłowo zreferowanego ujęcia interpretacyjnego należy się ustosunkować krytycznie ${ }^{14}$. Bo choć to wielorako uzasadnione ujęcie niewątpliwie jest słuszne, wnioski niekoniecznie, ponieważ już to nie mają one dostatecznego odzwierciedlenia w nomenklaturze k.k., już też w sferze wykładni i stosowania prawa karnego wywołują konsekwencje, które w żadnym razie na akceptację nie zasługuja.

Chodzi o to, że w świetle art. $240 \S 1$ k.k. odpowiedzialności karnej podlega ten, kto mając wiarygodną wiadomość o karalnym usiłowaniu lub dokonaniu m.in. czynu zabronionego określonego w art. $148 \S 1$ k.k., zaniecha niezwłocznego zawiadomienia o tym organu powołanego do ścigania przestępstw. Czy wobec tego, że - przykładowo - podżegacz popełnia własne przestępstwo, mające odrębny zestaw znamion, inne od przestępstwa bezpośredniego wykonawcy i przekracza inną normę sankcjonowaną zrębowo i centralnie zakodowana w art. $18 \S 2$ k.k., o którym to podżegaczu nie można powiedzieć, że swoim czynem „zabił” człowieka, lecz że „nakłaniał do zabicia”, to zaniechanie zawia-

11 Pohl (2007): 145-147.

12 Pohl (2007): 147; (2018b): 124.

13 Patryas (1993): 28-29. Zob. też Pohl (2018a): 9.

14 Należy koniecznie wspomnieć, że Pohl - wychodząc z tych samych pozycji argumentacyjnych - stanowczo kwestionuje dopuszczalność pociagnięcia nieletniego do odpowiedzialności karnej za niewykonawcze formy współdziałania przestępnego po myśli art. 10 § 2 k.k. Zob. Pohl (2010): 163-176; (2018a): 7-18; (2018b): 116-143; (2019): 140-142. W skrócie stanowisko Pohla w tym zakresie sprowadza się do takiej wykładni zawartego w art. $10 \S 2 \mathrm{k} . \mathrm{k}$. ustawowego odesłania „czynu zabronionego określonego w art” - odesłania wyłącznie do określonych przepisów części szczególnej k.k. - która prowadzi do jednoznacznie negatywnej odpowiedzi na pytanie, czy rzeczone odesłanie dotyczy także niewykonawczych form współdziałania przestępnego (oraz form przeddokonania). W epilogu swoich ustaleń Pohl (2010: 176) formułuje dwa alternatywne postulaty de lege ferenda idące w kierunku uzupełnienia art. $10 \S 2$ k.k. formułą: „lub czynu zabronionego będącego formą jego popełnienia” tudzież formuła „lub czynu zabronionego będącego forma popełnienia czynu zabronionego określonego we wskazanych przepisach”. 
domienia organu ścigania o przestępstwie podżegania do zabójstwa nie wyczerpuje znamiona czynu zabronionego $\mathrm{z}$ art. $240 \S 1 \mathrm{k} . \mathrm{k} . ?$

W świetle zreferowanego już ujęcia odpowiedź na to pytania musi być negatywna, ponieważ w art. $240 \S 1$ k.k. ustawa - analogicznie jak czyni to w art. $10 \S 2$ k.k. - odsyła przecież wyłącznie do określonych przepisów części szczególnej k.k., nie odsyła zaś wcale do niewykonawczych form współdziałania przestępnego. $\mathrm{Z}$ wielu powodów jest to przecież wykładnia absurdalna. Trudno byłoby nawet próbować sensownie uzasadnić twierdzenie, że niezawiadomienie niezwłocznie organu ściagania o sprawstwie kierowniczym, podżeganiu czy pomocnictwie do dokonania zabójstwa oraz usiłowaniu zabójstwa (nawet gdy chodzi o sprawstwo wykonawcze!) w ogóle nie podpada pod art. 240 $\S 1 \mathrm{k.k.}{ }^{15}$ A właśnie taki jest pewny efekt twierdzenia, że w części szczególnej k.k. przedmiotem typizacji są wykonawcze formy współdziałania oraz że artykułowe odesłania do przepisów części szczególnej k.k. mają na względzie tylko zachowania polegajace na wykonaniu czynu zabronionego.

Rozważmy inny przykład, związany z art. 93c pkt 3 k.k. Czy można podstawnie twierdzić, że zredagowane tam odesłanie artykułowe „określone w art. 148, art. 156, art. 197, art. 198, art. $199 \S 2$ lub art. $200 \S 1$ ”, a więc bez wyjątku odesłanie tylko do określonych typów czynów zabronionych pod groźbą kary określonych w części szczególnej k.k., generalnie nie odnosi się do niewykonawczych form współdziałania przestępnego? I na to pytanie odpowiedź musi być jednoznacznie negatywna ${ }^{16}$. Odmienne ustalenie zmuszałoby do przyjęcia, zgodnie z którym nie jest dopuszczalne orzeczenie środków zabezpieczających po myśli art. 93c pkt $3 \mathrm{k} . \mathrm{k}$. ani wobec sprawcy kierowniczego, ani sprawcy polecającego, ani podżegacza, ani też pomocnika do zabójstwa popełnionego w związku z zaburzeniem preferencji seksualnych.

Z kolei na gruncie $277 \mathrm{~b}$ k.k. powstaje kwestia niedopuszczalności wymierzenia podwyższonej grzywny kumulatywnej wobec sprawców popełniających określone tam typy czynów zabronionych w formach niewykonawczych $^{17}$. Wszakże samym tylko podżeganiem nie sposób ani „podrobič” faktury

15 Ponieważ samym tylko usiłowaniem nie sposób intencjonalnie wytworzyć skutku w postaci śmierci człowieka, czyli dokonać zabójstwa, w związku z czym usiłowanie zabójstwa nie jest zabójstwem. Zob. Pilarczyk (2014): 85. Jest to refleks ogólniejszej reguły, wedle której usiłowanie i dokonanie to dwa czyny całkiem różne, w związku z czym usiłowanie to odrębny - w stosunku do dokonania - typ czynu zabronionego. Zob. Pohl (2007): 135-139.

${ }^{16} \mathrm{~W}$ literaturze przedmiotu dopuszczalność orzeczenia środków zabezpieczających wobec podżegacza i pomocnika po myśli art. 93c pkt $3 \mathrm{k} . \mathrm{k}$. słusznie nie jest kwestionowana, a nadto akcentuje się niezbędność takiego rozwiązania z punktu widzenia ochronnej funkcji środków zabezpieczających. Zob. Barczak-Oplustil (2016): 759-760.

17 Za nieistotny dla prowadzonych tu rozważań uważam fakt, że w niektórych przypadkach ustawa operuje formułą „,czynu zabronionego określonego w art.”, niekiedy zaś „przestępstwa określonego w art.”. Sedno sprawy tkwi w pytaniu, jak należy pojmować rzeczone odesłania: 1) szeroko - jako obejmujące wszystkie formy popełnienia przestępstwa (wykonawcze formy współdziałania przestępnego, a także usiłowanie oraz karalne przygotowanie); 2) wąsko - jako obejmujące wyłącznie wykonawcze formy współdziałania przestępnego. Chodzi więc głównie o to, czy tego rodzaju odesłania artykułowe do części szczególnej k.k. odnoszą się także do rozwiązań z części ogólnej k.k. Należy stanowczo przyjąć, że zupełnie analogiczne pytanie dotyczy również mniejszych jednostek redakcyjnych tekstu prawnego (paragrafów), w których następuje odesłanie 
(art. 270a $§ 1$ k.k.), ani jej „wystawić” (art. 271a § 1 k.k.), a przecież w art. 277b $\S 1$ k.k. jest jedynie odesłanie do art. $270 \mathrm{a} \S 1 \mathrm{k} . \mathrm{k}$. i art. $271 \mathrm{a} \S 1 \mathrm{k} . \mathrm{k} .$, czyli do zachowania opisanego odpowiednio jako „kto podrabia” i „kto wystawia”, a nie do „nakłaniania do podrobienia” i „nakłaniania do wystawienia”. To samo mutatis mutandis - jest na gruncie art. $309 \mathrm{k} . \mathrm{k}$. i nie jest dopuszczalne orzeczenie grzywny w podwyższonej wysokości np. wobec podżegacza do dokonania przestępstwa z art. $297 \S 1 \mathrm{k} . \mathrm{k}$. Jest przecież oczywiste, że we wszystkich tych przypadkach następuje odesłanie do określonego przepisu części szczególnej k.k. i ani słowem ustawa nie wspomina o niewykonawczych formach współdziałania przestępnego.

Ta zaledwie nikła próbka wyraźnie obrazuje efekty, do jakich prowadzi forsowanie stanowczej tezy, że przepisy części szczególnej k.k. lub ustawy pozakodeksowej nastawione są wyłącznie na wykonanie czynu zabronionego i generalnie zamknięte są na niewykonawcze formy współdziałania przestępnego. Ten sam efekt dotyka zresztą wielu innych licznych kodeksowych rozwiązań, w których następuje bądź artykułowe odesłanie do przepisu/ przepisów części szczególnej k.k. (por. art. 131, art. $169 \S 1$ i 2, art. $176 \S 1$ i 2, art. 185 $\S 1-3$, art. $213 \S 1$ i 2 , art. 237 , art. $252 \S 5$, art. 269 c, art. 277 a $\S 1$, art. 277 b, art. 277 c $\S 3$, art. $283,294 \S 1$, art. $295 \S 1$, art. $307 \S 1$ i art. 309), bądź do całych rozdziałów części szczególnej k.k. (por. art. 41a § 3a, art. $101 \S 4$ pkt 2). Nie inaczej jest także na gruncie ustawy karnoprocesowej oraz pozakarnych dziedzin prawa. Nasuwa się pytanie, czy w kontekście tych wszystkich przepisów należy całą rzecz pojmować analogicznie jak na tle art. 10 § 2 k.k. i przyjmować w sposób ogólny, że zawarte tam odesłania mają na względzie tylko sprawstwo wykonawcze. Oczywiście, że nie. Trudno bowiem dostrzec racje, dla których np. sprawca kierowniczy kradzieży rzeczy ruchomej znacznej wartości nie miałby odpowiadać z uwzględnieniem art. $294 \S 1$ k.k., lecz jedynie za kradzież typu zasadniczego z art. $278 \S 1$ k.k. Jest przecież oczywiste, że wedle zreferowanych na wstępie założeń sprawca kierowniczy nie może „zabrać cudzej rzeczy ruchomej w celu przywłaszczenia” i tym samym dopuścić się „przestępstwa określonego w art. $278 \S 1$ ” w rozumieniu art. $294 \S 1$ k.k. Sprawca ten może być wykonawcą czynu innego rodzaju, czynu, który - nie bardzo zreszta wiadomo dlaczego - ustawa w art. $294 \S 1$ k.k. pomija całkowitym milczeniem.

IV. Należy z naciskiem podkreślić, że jeżeli k.k. w sposób artykułowy odsyła do konkretnego typu czyn zabronionego określonego w części szczególnej k.k. bądź ustawy pozakodeksowej, odesłanie to oznacza, iż typ ten może być in concreto popełniony w ramach wszystkich sześciu sposobów popełnienia prze-

do określonych rozwiązań części szczególnej k.k. oraz - także analogicznie - całych zespołów jednostek redakcyjnych tekstu prawnego (odesłań do całych rozdziałów części szczególnej k.k.). Przypomnijmy zaś, że reguła brzmi: odesłanie do przepisu części szczególnej k.k. nie służy oznaczaniu takich zachowań, jak: sprawstwo kierownicze, sprawstwo polecające, podżeganie, pomocnictwo oraz usiłowanie - zob. Pohl (2018b): 133. Z punktu widzenia powyższej reguły wszystkie te odesłania należy traktować jednakowo. Nie ma więc żadnego znaczenia, czy odesłanie następuje do artykułu, paragrafu, czy całego rozdziału części szczególnej k.k. 
stępstwa opisanych $\mathrm{w}$ art. $18 \mathrm{k} . \mathrm{k}$. W tym sensie np. podżegacz i pomocnik do dokonania zabójstwa człowieka „zabija”, a podżegacz i pomocnik do dokonania kradzieży - „kradnie”18. Jeżeli więc sprawca współdziałał w przestępstwie w formie niewykonawczej), to i tak w nomenklaturze k.k. jest on zawsze traktowany jako sprawca wykonawczy. Tym samym nie ma w polskim prawie karnym reguły: ile przekroczonych norm sankcjonowanych, tyle popełnionych przestępstw. Jest za to reguła: jedno przestępstwo - niezależnie od tego, ile w ramach współdziałania przestępnego przekroczonych norm sankcjonowanych. Nie jest to żadna korekta rzeczywistości ${ }^{19}$.

Nie ulega wątpliwości, że k.k. nazywa po prostu „zabójstwem” zabicie człowieka w jakiekolwiek formie współdziałania przestępnego i że nie ma w obowiąującym k.k. odrębnej nazwy prawnej „kierowanie wykonanie zabójstwa przez inną osobę”, ale jest ogólna „zabójstwo” (por. art. $101 \S 1$ pkt 1 , $105 \S 2$, art. 148 §). W przeciwnym razie należałoby przyjąć dość osobliwe rozwiązanie, zgodnie z którym ulega przedawnieniu karalność np. sprawstwa kierowniczego zabójstwa popełnione przez funkcjonariusza publicznego w związku z pełnieniem obowiązków służbowych, natomiast nie ulega przedawnieniu jedynie dokonane zabójstwo popełnione przez funkcjonariusza publicznego w ramach sprawstwa pojedynczego i współsprawstwa. Należy też stwierdzić, że zawarte w przepisach k.k. odesłanie nazwowe do określonego typu czynu zabronionego dotyczy zawsze wszystkich form popełnienia przestępstwa (zjawiskowych i stadialnych) ${ }^{20}$. Takie stanowisko formułowano

${ }_{18}$ Niczego w tym względzie nie zmienia ani to, że podżeganie i pomocnictwo cechują się ,autonomicznymi czynnościami sprawczymi” - zob. Sakowicz (2017): 426, ani też to, iż „realizacja bowiem konkretnego typu czynu zabronionego w któreś z postaci sprawczych określonych w art. 18 $\S 1$ k.k. ma zupełnie odmienny charakter niż nakłanianie lub udzielenie pomocy do popełnienia tego przestępstwa" - zob. Wróbel, Zoll (2011): 267: Powyższych poglądów nie należy przecież pojmować w ten sposób, że zaniechanie niezwłocznego niezawiadomienie organu powołanego do ścigania przestępstw o dokonanym podżeganiu lub pomocnictwie do zabójstwa nie podpada pod art. $240 \S 1$ k.k., ponieważ - przykładowo - podżeganie do zabójstwa ” nie jest „zabiciem człowieka”, a więc nie stanowi „czynu zabronionego określonego w art. 148 k.k.” w rozumieniu art. 240 $\S 1$ k.k.

${ }^{19}$ Powyższe ustalenie ma silne uzasadnienie w treści przepisu art. $60 § 3$ k.k. Uzmysławia to następujący przykład: A podżega B do zabójstwa C (art. 148 § 1 k.k.). Do tego czynu pomocy B udziela D. B dokonuje zabójstwa C. Kwalifikacja prawna wszystkich tych czynów przedstawia się

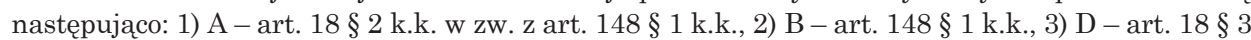
k.k. w zw. z art. $148 \S 1$ k.k. Jak widać, przekroczono trzy różne normy sankcjonowane, zakazujące trzech różnych zachowań i popełniono trzy różne przestępstwa, mające własne zestawy znamion. Zaskakujący jest jednak fakt, że wedle art. $60 § 3$ k.k. (verba legis: „w popełnieniu przestępstwa”) popełniono jedno przestępstwo i wszyscy sprawcy (A, B i D) współdziałali ze sobą w jego popełnieniu. Co więcej, gdyby A nakłonił B, będąca matka, do zabicia jej dziecka w okresie porodu pod wpływem jego przebiegu, natomiast D udzielił B pomocy do dokonania tego czynu, dalej byłoby to współdziałanie trzech osób w jednym przestępstwie w rozumieniu art. 60 § $3 \mathrm{k}$.k. Ale przecież B odpowiadałaby za dzieciobójstwo, natomiast A i D - za zwykłe zabójstwo. Jak łatwo dostrzec, ustawodawca dość swobodnie podchodzi do zagadnienia liczby przekroczonych norm sankcjonowanych i nawet jeśli in concreto są to trzy różne normy, jedno jest przestępstwo (zabójstwo).

${ }^{20}$ Przemawia za tym jurydyczna racjonalność prawodawcy. Jak wiadomo, prawodawca racjonalny zna orzecznictwo sądowe i literaturę prawnicza - adekwatne do wprowadzanej przez siebie regulacji. Zob. Zieliński (2017): 265. Wiadomo również, że prawodawca racjonalny nie pisze tekstów prawnych na prawniczej, w tym terminologicznej i pojęciowej, pustyni. Zob. Zieliński (2011): 25. 
już na gruncie art. 9 § 2 k.k. z 1969 r. i nie ma żadnego powodu, aby od niego odstępować ${ }^{21}$.

Gdyby istotnie przytaczane założenia ściśle konsekwentnie stosować w sferze wykładni i stosowania poszczególnych rozwiązań kodeksowych, prowadziłoby to do tego, że np. pomocnictwo do zniesławienia ścigane jest $\mathrm{z}$ urzędu, skoro - w myśl art. $212 \S 4$ k.k. - ściganie prywatnoskargowe dotyczy wyłącznie „przestępstwa określonego w $§ 1$ i 2 ” art. 212 k.k., a więc zniesławienia popełnionego wyłącznie w ramach samoistnego sprawstwa i współsprawstwa. Nie ulega przecież żadnych wątpliwości, że podżegacz do dokonania zniesławienie nigdy nie jest „sprawcą czynu zabronionego określonego w § 1” art. 212 k.k. W przepisie tym przecież sprecyzowano, że zakazany czyn polega na „pomówieniu” (verba legis: „pomawia”), nie zaś na „nakłanianiu do pomówienia”. Generalnie bioracc, analogicznie chyba należałoby wykładać wszystkie tego rodzaju odesłania kodeksowe - i to nie tylko odnoszące się do trybu ścigania. Ta-

Nie jest więc tak, że racjonalny prawodawca dowolnie kształtuje znaczenie karnoprawnych określeń od lat występujących w tekstach aktów prawnych i nie liczy się z ustaleniami interpretacyjnymi literatury prawniczej lub orzecznictwa sądowego. Jeżeli więc pracodawca w k.k. z 1997 r. posłużył się bez zmiany określonym terminem występującym już w k.k. z 1969 r., to należy przyjąć, że uznał on zastaną wykładnię doktrynalną tego terminu za słuszna, i należy ją respektować de lege lata. Ponieważ określenie „ciężkie uszkodzenie ciała” użyte w art. 9 § 2 k.k. z 1969 r. odnosiło się do wszystkich ówcześnie znanych k.k. form popełnienia czyn zabronionego (nie wyłączając podżegania i pomocnictwa, a także usiłowania) - tak Mioduski (1987): 51 i ustawodawca przy tworzeniu k.k. z 1997 r. ustalenia te znał i je przyjął, to należy uznać, że zupełnie identyczne znaczenie ustawodawca przypisuje wyrażeniu „ciężkie uszkodzenie ciała” na tle art. $105 \S 2$ k.k. - poszerzając jego zakres o sprawstwo polecające, nieznane na gruncie k.k. z 1969 r. Jeżeli więc $\mathrm{w}$ art. $105 \S 2$ k.k. ustawodawca używa określenia „ciężkie uszkodzenie ciała”, to z pewnością dotyczy to także podżegacza i pomocnika. Słowem, sprawca np. podżegania do spowodowania ciężkiego uszkodzenia ciała - w nomenklaturze k.k. - może być autorem zmiany w świecie zewnętrznym polegającej na „ciężkim uszkodzeniu ciała”. Pozbawione podstaw w ustawie jest więc twierdzenie, że na tle art. $105 \S 2$ k.k. chodzi o czyny popełnione w postaci sprawczych form współdziałania przestępnego, a więc z wyłączeniem podżegania i pomocnictwa. Zob. Zoll, Tarapata (2016): 861. Trudno przeczyć, że w całej tej materii ustawowe określenie „zabójstwo” ma identyczne znaczenie na tle art. $101 \S 1$ pkt 1 k.k., art. $105 \S 2$ k.k. czy art. 148 § 3 k.k. oraz że 30-letni okres przedawnienia karalności zbrodni zabójstwa dotyczy także podżegania, pomocnictwa i usiłowania zabójstwa (a sprawcy tych czynów są po prostu sprawcami zabójstwa, a więc tymi, którzy zrealizowali czasownikowe znamię „zabija”). Chyba że mamy przyjmować, iż np. podżeganie (oraz usiłowanie) zabójstwa stanowi „inną zbrodnię” w rozumieniu art. $101 \S 1$ pkt 2 k.k., których karalność przedawnia się już po 20 latach, natomiast wcześniejsze prawomocne skazanie „za zabójstwo” (art. 148 § 3 k.k.) w ogóle nie dotyczy niewykonawczych form współdziałania przestępnego (oraz usiłowania).

${ }^{21}$ Nie ulega przecież wątpliwości, że różnica pomiędzy spotykanymi w k.k. odesłaniami nazwowymi (por. np. art. $64 \S 2$, art. $101 \S 1$ pkt 1, art. $105 \S 2$ ), a odesłaniami artykułowymi (por. np. art. $10 \S 2$, art. 93c pkt 3 , art. $145 \S 1$ pkt 2 lit. a, art. $294 \S 1$ ), sprowadza się wyłącznie do tego, że odesłanie nazwowe może być rozciagnięte również na pozakodeksowe przepisy karne, w których byłyby określone typy czynów zabronionych odpowiadające nazwom użytym w takim odesłaniu, natomiast odesłanie artykułowe działa wyłącznie w obrębie k.k. Taki właśnie wniosek wprost wynika ze stanowiska Andrejewa (1986: 21) i Mioduskiego (1987: 51) sprecyzowanego na gruncie art. $9 \S 2$ k.k. z 1969 r. Z tego punktu widzenia wprowadzenie do art. $10 \S 2$ k.k. odesłania artykułowego - w miejsce przewidzianego w art. 9 § 2 k.k. z 1969 r. odesłania nazwowego zawęża jedynie zakres tego odesłania i w żadnym razie nie wiąże się z rzekomym wyłączeniem dopuszczalności pociagnięcia nieletniego do odpowiedzialności karnej za niewykonawcze formy współdziałania przestępnego na podstawie art. $10 \S 2$ k.k. 
kich odesłań do konkretnych paragrafów należących do części szczególnej kodeksu jest przecież w k.k. całe mnóstwo (por. np. $121 \S 2$, art. $152 \S 3$, art. 153 $\S 2$, art. $154 \S 1$ i 2 , art. $156 \S 3$, art. $160 \S 3,173 \S 3,190$ a § 3, art. $197 \S 4$, art. $199 \S 2$, art. $212 \S 2,252 \S 2$, art. $289 \S 2,3$ i 4, art. 296a § 4).

V. Przyjęcie, że tego rodzaju paragrafowe odesłania należy pojmować tak samo, jak odesłania artykułowe (na tle art. $10 \S 2$ k.k.), zmusza też do przyjęcia, iż odesłania paragrafowe dotyczą wyłącznie wykonania czynu zabronionego. Wszakże oba te typy odesłań dotyczą konkretnego typu czynu zabronionego określonego w części szczególnej k.k. i do części ogólnej k.k. nie odsyłaja. Oznacza to, że punktem odniesienia tego rodzaju odesłań muszą być wyłącznie zachowania polegające na wykonaniu czynu zabronionego. Z tej perspektywy przeanalizujmy więc odesłanie zawarte w art. $197 \S 4$ k.k. Ponieważ w przepisie tym ustawa odsyła do „czynu określonego w § 1-3”, z pewnością więc nie odsyła do niczego, co znajduje się w części ogólnej k.k. (a to przecież w części ogólnej k.k. zakodowane są normy sankcjonowane zakazujące zachowań opisanych w ustawie jako niewykonawcze formy współdziałania oraz usiłowań22). Uzyskujemy wówczas następujące rozwiązanie: podżegacz, sprawca kierowniczy, sprawca polecający i pomocnik) do dokonania zgwałcenia ze szczególnym okrucieństwem odpowiada za typ podstawowy zgwałcenia z art. $197 \S 1$ k.k. Jest przecież oczywiste, że samym podżeganiem - tak jak nie można zabić człowieka - tak samo nie sposób wytworzyć stanu rzeczy, który ustawa w art. 197 $\S 1$ k.k. opisuje formuła „doprowadza inną osobę do obcowania płciowego”, lecz co najwyżej można "nakłonić inną osobę do doprowadzenia innej osoby do obcowania płciowego". To zachowanie zostało jednak pominięte w odesłaniu sprecyzowanym w art. $197 \S 4$ k.k.

Prowadzi to jednak niezawodnie do zanegowania ogólnej zasady określonej w art. $19 \S 1$ k.k., zgodnie z którą sąd wymierza karę za podżeganie lub pomocnictwo w granicach zagrożenia przewidzianego za sprawstwo. Należy bowiem zwrócić uwagę, że w podanym przykładzie czyn popełniony w ramach niewykonawczej formy współdziałania (podżegania) będzie kwalifikowany inaczej (łagodniej - z art. 18 § 2 k.k. w zw. z art. $197 \S 1$ k.k.) w stosunku do kwalifikacji czynu popełnionego w ramach wykonawczych forma współdziałania (art. 197 § 4 k.k.). Prowadzi to z kolei do kwalifikacji sprzecznej z tym, do czego faktycznie zmierzał podżegacz, np. w podanym przykładzie podżegacza do zgwałcenia typu kwalifikowanego, kwalifikacje prawna jego czynu nastapi w ramach podstawowego typu zgwałcenia, mimo że podżegacz ten nakłaniał przecież do dokonania zgwałcenia ze szczególnym okrucieństwem. Kwalifikacja prawna dotyczyłaby więc czynu, którego podżegacz de facto nie chciał. On chciał przecież zgwałcenia kwalifikowanego, a nie zasadniczego. Tymczasem skądinąd wiadomo, że w celu ustalenia rodzaju i wysokości zagrożenia ustawowego za podżeganie i pomocnictwo „należy sięgnać do przepisu Części szczególnej, do którego odnoszą się czynności podżegacza [...]”23. Gdy sięgniemy do

${ }^{22}$ Zob. Pohl (2018b): 136-137.

${ }^{23}$ Sakowicz (2017): 474; nadto Kardas (2016): 474. 
tych czynności, wtedy okazuje się, że w podanym przykładzie czynności podżegacza w ogóle nie odnosiły się do zgwałcenia typu zasadniczego, ale do kwalifikowanego. Do typu kwalifikowanego nie można się jednak zwrócić, ponieważ jego sprawcą może być ten tylko, kto zrealizował znamię czasownikowe, kto wykonał czyn zabroniony, czyli w sposób opisany w art. 197 § 1 k.k. „doprowadził inną osobę do obcowania płciowego". Nie wystarczy, że sprawca nakłaniał inną osobę do wytworzenia tego stanu rzeczy ${ }^{24}$. W przepisie tym nie ma przecież mowy o nakłanianiu do obcowania płciowego, ale całkiem wyraźnie o zachowaniu opisanym jako „doprowadzenie do obcowania płciowego”. Jeżeli zatem ów podżegacz nie wykonał czynu polegającego na „doprowadzeniu innej osoby do obcowania płciowego", to tym samym nie może być on nigdy sprawca czynu zabronionego „określonego w § 1” w rozumieniu § 4 art. 197 k.k.

Należy stwierdzić, że przenoszenie na sferę wykładni i stosowania określonych rozwiązań prawnokarnych ustaleń o odrębności typów czynów zabronionych popełnionych w formach niewykonawczego współdziałania prowadzi wprost do wyników contra legem oraz do rozstrzygnięć jawnie kontrfaktycznych do tego jeszcze w sposób całkowicie niezrozumiały i niesłuszny wydatnie łagodzących odpowiedzialność karną za niewykonawcze współdziałanie w zgwałceniu ze szczególnym okrucieństwem. Należy je więc odrzucić.

VI. Ogólnie trzeba stwierdzić, że w analizowanej problematyce nie jest istotne, gdzie konkretnie ustawodawca koduje normy zakazujace niewykonawczych form współdziałania przestępnego, które są zrębowo i centralnie zawarte w art. 18 k.k., i jest to sprawa majacca znaczenie przede wszystkim na etapie stanowienia prawa (typizacji). Jeśli zaś chodzi o sposób odczytywania informacji normatywnych już na gruncie konkretnych przepisów części szczególnej k.k. bądź odesłań do przepisów części szczególnej k.k. (czy to w postaci artykułowej, paragrafowej, czy to odesłań do całych rozdziałów części szczególnej k.k.), to jest to już sprawa wykładni i stosowania ustawy. Można i należy uważać, że art. 18 k.k. wysłowia zrębowo i centralnie odpowiednie normy zakazujące sprawstwa kierowniczego, sprawstwa polecajacego, podżegania i pomocnictwa, ale jednocześnie przyjmować, iż przepisy typizujące części szczególnej k.k. dotyczą wszystkich form współdziałania przestępnego ${ }^{25}$.

${ }^{24}$ Należałoby więc de lege ferenda przepisowi art. $197 \S 4$ k.k. nadać następujące brzmienie: „Jeżeli sprawca czynu określonego w § 1-3 lub czynu zabronionego będącego formą popełnienia czynu zabronionego określonego we wskazanych przepisach, działa ze szczególnym okrucieństwem”. Zauważmy, że bez analogicznego uzupełnienia wszystkie typy kwalifikowane, odwołujące się w sposób paragrafowy do typu zasadniczego, mogłyby zostać popełnione jedynie w dwóch formach wykonawczych i jedynie jako dokonane, nigdy zaś w formach niewykonawczych ani w formie usiłowania. Dotyczyłoby to m.in. art. $212 \S 2$ k.k., art. $224 \S 3$ k.k., art. 229 § 3 k.k., art. 242 $\S 4$ k.k., art. 289 § 2 i 3 k.k. i art. 296 § 2 k.k.

${ }_{25}$ Odmienne ustalenie zmusza zaś do pytania o to, czy klauzule nieumyślności określone w k.k. odnoszą się li tylko do sprawstwa wykonawczego czy nadto do niewykonawczych form współdziałania. Jeśli bowiem uważać, że sprawstwo kierownicze, sprawstwo polecające, podżeganie i pomocnictwo mogą się odnosić także do nieumyślnych typów czynów zabronionych pod groźbą kary - tak Pohl (2019: 196-208) - i przyjmować ściśle konsekwentnie założenie o nastawieniu przepisów części szczególnej k.k. wyłącznie na sprawcze formy współdziałania, to należałoby też 
Nie ma w tym żadnej sprzeczności czy niekonsekwencji. Oba powyższe twierdzenie maja bowiem dwa odmienne zakresy odniesienia: pierwsze - tworzenie prawa, natomiast drugie - stosowanie prawa ${ }^{26}$.

$\mathrm{Z}$ tego punktu widzenia np. art. 149 k.k., i to już w warstwie deskryptywnej, należy odczytywać w sposób wskazujący nie tylko na jednosprawstwo i współsprawstwo, lecz także na wszystkie niewykonawcze formy współdziałania przestępnego oraz usiłowania, pomimo że w art. 149 k.k. wyraźnie nie ma słowa na temat sprawstwa kierowniczego ani sprawstwa polecającego, ani podżegania, ani pomocnictwa. W tym sensie matka nakłaniajaca inną osobę do zabicia jej dziecka w okresie porodu pod wpływem jego przebiegu może to dziecko „zabić” w rozumieniu art. 149 k.k. ${ }^{27}$ Tak po prostu redagowany jest Kodeks karny. Nie ma w tym niczego szczególnego. Jest za to wzgląd na ekonomię i syntetyczność ustawy, co zwycięża racje związane z radykalną wiernością określonym ustaleniom pochodzącym z prawoznawstwa ogólnego. Inaczej tekst k.k. miałby po prostu zbyt wiele dłużyzn. Należałoby bowiem wszystkie przepisy powyżej wymienione, zawierające odesłanie artykułowe i paragrafowe do przepisów części szczególnej k.k., uzupełniać każdorazowo formuła „lub czynu zabronionego będącego formą jego popełnienia” tudzież formułą „lub czynu zabronionego będącego formą popełnienia czynu zabronionego określonego we wskazanych przepisach". Przeczyłoby to istocie normatywnej przepisów art. 18 § 1-3 k.k. jako ogólnych, w których w sposób skondensowany pomieszczono cztery modyfikatory uzupełniające wyrażenie normokształtne sankcjonowane odpowiednim przepisem typizującym części szczególnej k.k. lub ustawy karnej pozakodeksowej (zakazujących niewykonawczych postaci współdziałania).

Należałoby również pójść $\mathrm{w}$ daleko posuniętą kazuistykę i tworzyć odrębne podstawy uprzywilejowanej odpowiedzialności karnej intraneusa za niewykonawcze formy współdziałania przestępnego. Takie posunięcie legislacyjne bliskie byłoby już sformułowanej niegdyś przez Bernharda Getza koncepcji współdziałania i wiązałoby się z przejęciem podstawowej wady tej koncepcji - koniecznością każdorazowego powtarzania w opisie przestępstwa indywidualnego niewłaściwego typu uprzywilejowanego klauzuli o niewyko-

przyjmować w sposób ogólny, że kodeksowe klauzule nieumyślności dotyczą wyłącznie wykonania czynu zabronionego. Klauzule nieumyślności są bowiem bez wyjątku zrelacjonowane właśnie do wykonania czynu zabronionego, gdyż odsyłaja - jak art. 10 § 2 k.k. - do określonego przepisu części szczególnej k.k. (por. jedynie przykładowo - art. 157 § 3, art. 160 § 3, art. 165 a § 4 czy $184 \S 3$, art. $296 \S 4$ ), a więc nie dotyczą zachowań innych niż wykonanie czynu zabronionego.

${ }^{26}$ Także wyłącznie $\mathrm{z}$ tworzeniem prawa ma powiązanie wypracowana $\mathrm{w}$ teorii prawa zasada normowania w jednej normie czynu tylko jednego rodzaju. Natomiast w sferze wykładni i stosowania prawa karnego należy generalnie przyjmować, że przepis typizujący części szczególnej k.k. dotyczy kompleksowo wszystkich form popełnienia przestępstwa w ujęciu rozdz. II k.k.

${ }^{27}$ Jest jasne, że matka dziecko „zabija” wyłącznie jako dzieciobójczyni. Nie podżega zaś do zabójstwa typu zasadniczego. Sięganie do typu zasadniczego nie jest konieczne do adekwatnego ukształtowania odpowiedzialności karnej matki. Co więcej, takie rozwiązanie nie jest dopuszczalne na gruncie lege lata. Dotyczy to także pomocnictwa. Chodzi o to, że pomiędzy zasadniczymi a zmodyfikowanymi typami czynów zabronionych zachodzi logiczny stosunek wykluczania (Pohl 2019: 250-252), nie jest więc możliwe, aby jeden i ten sam czyn wyczerpywał jednocześnie znamiona typu zmodyfikowanego i zasadniczego. 
nawczch formach współdziałania przestępnego. Aby tego niepożądanego efektu legislacyjnego uniknaćc, należy przyjąć w sposób generalny, że de lege lata w odniesieniu do przypadków, w których matka zabijanego dziecka niesprawczo współdziała w jego zabiciu, matka ta może być podmiotem dzieciobójstwa określonego w art. 149 k.k. ${ }^{28}$ Dla takiego ustalenia interpretacyjnego nie potrzeba uciekać się ani do przełamywania wyników wykładni językowej, ani do zmiany ustawy w obrębie art. $21 \mathrm{k} . \mathrm{k}$. Niczego w tym względzie nie zmienia już przejście z deskryptywnego poziomu odczytania tekstu prawnego na poziom dyrektywny, gdyż na obu tych poziomach pełną aktualność zachowuje wyróżnianie rodzajowego typu czyn zabronionego i określonych w k.k. form jego popełnienia.

\section{Kamil Siwek}

Uniwersytet im. Adama Mickiewicza w Poznaniu

kamil.siwek@amu.edu.pl

https://orcid.org/0000-0001-6901-0061

Andrejew, I. (1986). Kodeks karny. Krótki komentarz. Warszawa.

Barczak-Oplustil, A. (2016). [Komentarz do art. 93c], [w:] W. Wróbel, A. Zoll (red.), Kodeks karny. Część ogólna. Tom 1: Komentarz do art. 53-116. Warszawa: 759-770.

Kardas, P. (2016). [Komentarz do art. 19], [w:] W. Wróbel, A. Zoll (red.), Kodeks karny. Część ogólna. Tom 1: Komentarz do art. 1-52. Warszawa: 473-479.

Kluza, J. (2018). Odpowiedzialność karna intraneusa za sprawcze formy współdziałania w popełnieniu przestępstwa dzieciobójstwa. Prokuratura i Prawo 6: 15-24.

Księżopolska-Breś, A. (2010). Odpowiedzialność karna za dzieciobójstwa w prawie polskim. Warszawa.

Mioduski, K. (1987). [Komentarz do art. 9], [w:] J. Bafia, K. Mioduski, M. Siewierski, Kodeks karny. Komentarz. Tom 1. Warszawa: 49-53.

Patryas, W. (1993). Zaniechanie. Próba analizy metodologicznej. Poznań.

Pilarczyk, Ł. (2014). Analiza odpowiedzialności karnej ekstraneusa za przestępne współdziałanie w odniesieniu do podżegania i pomocnictwa. Ius Novum 4: 75-94.

Pohl, Ł. (2007). Struktura normy sankcjonowanej w prawie karnym. Zagadnienia ogólne. Poznań.

Pohl, Ł. (2010). O (nie)możliwości pociagnnięcia osoby nieletniej do odpowiedzialności karnej za tzw. niewykonawcze formy współdziałania przestępnego na gruncie kodeksu karnego z 1997 r., [w:] V. Konarska-Wrzosek, J. Lachowski, J. Wójcikiewicz (red.), Węzłowe problemy prawa karnego, kryminologii i polityki kryminalnej. Księga pamiątkowa ofiarowana Profesorowi Andrzejowi Markowi. Warszawa: 163-176.

Pohl, Ł. (2013). O prawnokarnych ocenach realizowanego w okresie porodu i pod wpływem jego przebiegu nie wykonawczego współdziałania przestępnego matki z osobą dopuszczającą się lub mogącą się dopuścić zabójstwa jej dziecka w tym okresie, [w:] A. Błachnio-Parzych, J. Jakubowska-Hara, J. Kosonoga, H. Kuczyńska (red.), Problemy wymiaru sprawiedliwości karnej. Księga Jubileuszowa Profesora Jana Skupińskiego. Warszawa: 291-303.

Pohl, Ł. (2018a). Zakres odpowiedzialności karnej nieletniego w Kodeksie karnym z 1997 r. (o konieczności pilnej zmiany art. $10 \S 2$ k.k. - problem form popełnienia czynu zabronionego). Prawo w Działaniu. Sprawy Karne 30: 7-18.

Pohl, Ł. (2018b). Ponownie w sprawie zakresu odpowiedzialności karnej osoby nieletniej według Kodeksu karnego z 1997 r. (zagadnienie form popełnienia czynu zabronionego) - uwagi o metodzie rozwiązania problemu. Prawo w Działaniu. Sprawy Karne 35: 116-143.

Pohl, Ł. (2019). Prawo karne. Wykład części ogólnej. Warszawa.

28 Tak tė̇ Księżopolska-Breś (2010): 114. 
Sakowicz, A. (2017). [Komentarz do art. 19], [w:] M. Królikowski, R. Zawłocki (red.), Kodeks karny. Część ogólna. Komentarz: Art. 1-116. Warszawa: 473-475.

Wróbel, W., Zoll, A. (2011). Polskie prawo karne. Część ogólna. Kraków.

Zieliński, M. (2011). Osiemnaście mitów w myśleniu o wykładni prawa. Palestra 3/4: 20-37.

Zieliński, M. (2017). Wykładnia prawa. Zasady. Reguły. Wskazówki. Warszawa.

Zoll, A., Tarapata, S. (2016). [Komentarz do art. 105], [w:] W. Wróbel, A. Zoll (red.), Kodeks karny. Część ogólna. Tom 1: Komentarz do art. 53-116. Warszawa: 856-861.

\section{INTRANEUS' CRIMINAL LIABILITY FOR NON-EXECUTIVE FORMS OF CRIMINAL CO-OPERATION (REMARKS IN THE CONTEXT OF THE CRIME OF INFANTICIDE)}

\section{Summary}

The subject of the study is a highly controversial issue related to the criminal law assessment of an intraneus act for non-executive forms of criminal cooperation, which is discussed in the literature on criminal law. Deliberations are conducted in the context of the crime of infanticide specified in Article 149 of the Penal Code. As a result of the deliberations, the author determines that in the legal language of the Penal Code a given type of prohibited act specified in the special part of the Penal Code or the Non-Codex Criminal Act, it always refers to all forms of committing a prohibited act in terms of Chapter II of the Penal Code: executive, non-executive forms, as well as stadium forms.

Keywords: phenomenal forms of committing a crime; infanticide; legal classification; individual crime; interpretation of law 